\title{
Effect of Spacer Length on Recovery of Acid Protease from Raw Shoyu by Pepstatin-Sepharose Affinity Chromatography
}

\author{
Yaichi Fukushima, Kazuya Hayashi and Hiroshi MotaI \\ Research and Development Division, Kikkoman Corporation, \\ Noda-shi, Chiba 278, Japan \\ Received October 2, 1984
}

\begin{abstract}
In order to investigate the effect of the spacer in pepstatin-Sepharose on adsorption and elution of acid protease (AcP) in raw shoyu (unpasteurized soy sauce), a homologous pepstatin-aminoalkyl agarose series, (pepstatin- $\mathrm{NH}_{2}\left(\mathrm{CH}_{2}\right)_{n}$-Sepharose), that varied as to the length of the hydrocarbon chains was synthesized. When raw shoyu containing many kinds of proteases was subjected to affinity chromatography on these pepstatin- $\mathrm{C}_{n}$-Sepharoses $(n=2,4,6,8,10$ and 12), all of them adsorbed AcP. With increasing length of the spacer up to 6, more and more AcP became adsorbed onto the pepstatin- $\mathrm{C}_{n}$-Sepharose, whereas with decreasing length of the spacer, more and more AcP was eluted with $0.05 \mathrm{~m}$ acetate buffer ( $\mathrm{pH} 3$ ) containing $2 \mathrm{~m}$ urea. The AcP was purified in one step from raw shoyu and did not have any carboxypeptidase activity. Some properties of the major component of the eluted AcPs were as follows: molecular weight, $6.7 \times 10^{4}$, on gel filtration with TSK-G3000SW, optimum $\mathrm{pH}$ for activation of trypsinogen, 3.5, optimum $\mathrm{pH}$ for hydrolysis of hemoglobin, 2.75, and the $K i$ value toward pepstatin, $1.0 \times 10^{-8} \mathrm{M}$.
\end{abstract}

Shoyu (Japanese type fermented soy sauce) $)^{1)}$ is the product of a complex fermentation in which a mixture of soybeans and wheat is cultured with a koji mold, Aspergillus sojae or Aspergillus oryzae, and the resulting mass, koji, is placed in brine. The resultant mixture, moromi mash, is kept for several months with appropriate temperature control. Enzymatic digestion of raw materials and lactic and alcoholic fermentations occur during the fermentation period. The matured moromi mash is squeezed through layers of cloth under high pressure, and the resultant clear solution is called raw shoyu (unpasteurized soy sauce). Many kinds of enzymes produced by Koji molds partly remain in the raw shoyu $(\mathrm{NaCl}$; approx. $17 \%$ ) after several months of brine fermentation and are excluded as coagula on heating during the pasteurization process. ${ }^{2)}$ AcP is known to be one of the most stable enzymes during the fermentation process, and a considerable quantity of active $\mathrm{AcP}$ protein exists in raw shoyu. In order to utilize the AcP in the raw shoyu, we attempted to recover the AcP by means of pepstatin affinity chro- matography.

Pepstatin- $\mathrm{C}_{6}-$ Sepharose had been previously used for the isolation of AcPs such as ren$\operatorname{nin}^{3,4)}$ and renin ${ }^{5)}$ etc. As their $K i$ values were high, they were easily eluted. When the $K i$ value of an AcP was lower than $1.0 \times 10^{-7}$, the AcP could not be eluted anymore, because of its tight adsorption. ${ }^{6)}$ To decrease the inhibitory activity of the ligand, $\mathrm{N}$-acetyl pepstatin instead of pepstatin was used and milk clotting enzymes from Mucor miehei could be eluted. ${ }^{6}$ ) An equally good decrease in the strength of adsorption was achieved by decreasing the length of the spacer between the ligand and the agarose. We found that decreasing the length of the spacer was one means of elution of a tightly adsorbed ligate and we could recover AcP from raw shoyu by applying this phenomenon.

\section{MATERIALS AND METHODS}

Sepharose 6B was obtained from Pharmacia Fine Chemicals (Sweden), and $\mathrm{NH}_{2}\left(\mathrm{CH}_{2}\right)_{n} \mathrm{NH}_{2}(n=2,4,6,8$, 10 and 12) were from Wako Pure Chemical Industries 
(Japan). Pepstatin was purchased from the Protein Research Foundation (Japan). Other reagents were commercially available reagents. Raw shoyu was prepared by the conventional method ${ }^{1)}$ on a laboratory scale using the koji mold, A. sojae.

High speed gel filtration. High speed gel filtration was carried out as described by Motai et al. ${ }^{7}$

Assay of AcP activity. The enzyme activity was assayed by three methods: 1) by a modification of Anson's meth$\mathrm{od}^{8)}$ with milk casein as substrate, 2) by a modification of Anson's method ${ }^{8)}$ with hemoglobin as substrate, and, 3) activation of trypsinogen by AcP was determined by the methods of Gabeloteau et al..$^{9)}$ and Abita et al. ${ }^{10)}$

Assay of carboxypeptidase activity. Carboxypeptidase activity was assayed after $24 \mathrm{hr}$ at $\mathrm{pH} 3$ and $30^{\circ} \mathrm{C}$ using synthetic substrates, such as Z-Glu-Tyr (Z; benzyloxycarbonyl), Z-Tyr-Leu and Z-Phe-Tyr by Ichishima's method. ${ }^{11)}$

Determination of coagula. After the raw shoyu had been heated at $85^{\circ} \mathrm{C}$ for $20 \mathrm{~min}$, rapidly cooled to $55^{\circ} \mathrm{C}$ and kept at the same temperature for two days, turbidity was determined with a Corona Turbidimeter (UT-11) as described by Motai et al. ${ }^{7}$

Determination of Ki. Determination of $K i$ values of AcPs toward pepstatin was performed by Dixon's method. ${ }^{12)}$

Gel electrophoresis. Gel electrophoresis was performed by the method of Williams et al. ${ }^{13)}$

Preparation of affinity gel. Activation of Sepharose 6B with cyanogen bromide was performed by the method of Turková ${ }^{15)}$ as follows; $8 \mathrm{mmol}$ of each $\mathrm{NH}_{2}\left(\mathrm{CH}_{2}\right)_{n} \mathrm{NH}_{2}$ $(n=2,4,6,8,10$ and 12) was coupled with $6 \mathrm{~g}$ of activated Sepharose $6 \mathrm{~B}$ (wet weight) by slow stirring at $4^{\circ} \mathrm{C}$ for $16 \mathrm{hr}$. After coupling, Sepharose- $\mathrm{C}_{n}-\mathrm{NH}_{2}(n=2,4,6,8,10$ and 12) were successively washed with the following solutions, $350 \mathrm{ml}$ of $0.5 \mathrm{M} \mathrm{NaCl}, 200 \mathrm{ml}$ of water, and $70 \mathrm{ml}$ of ethanol and dioxane $(1: 1)$. Pepstatin was coupled to sepharose- $\mathrm{C}_{n}-\mathrm{NH}_{2}$ as described by Murakami et al. ${ }^{5)}$

Adsorption and elution of AcP. The raw shoyu (approx. $1200 \mathrm{ml}$ ) was applied to a Sepharose- $\mathrm{C}_{n}$-pepstatin column $(0.6 \times 3.5 \mathrm{~cm})$ equilibrated with $0.05 \mathrm{M}$ acetate buffer $(\mathrm{pH}$ 4.5 ) at the flow rate of $7.2 \mathrm{ml}$. The column was washed with the same buffer and the AcP was eluted with $2 \mathrm{M}$ urea in $0.05 \mathrm{M}$ acetate buffer $(\mathrm{pH} 3)$ at the flow rate of $2 \mathrm{ml} / \mathrm{hr}$. The eluted AcP was immediately diluted three-fold with $0.05 \mathrm{M}$ acetate buffer ( $\mathrm{pH} 4.5)$, concentrated by ultrafiltration and then dialyzed against $0.05 \mathrm{M}$ acetate buffer $(\mathrm{pH}$ 4.5) for $12 \mathrm{hr}$. All experiments were carried out at $4^{\circ} \mathrm{C}$.

\section{RESULTS AND DISCUSSION}

\section{Effect of spacer length}

A homologous $\omega$-aminoalkyl-agarose series which varied as to the length of the $\omega$ aminoalkyl side chains (Sepharose- $\mathrm{C}_{n}-\mathrm{NH}_{2}$ ) was synthesized by activation of Sepharose 6B with CNBr. Pepstatin was coupled to Sepharose- $\mathrm{C}_{n}-\mathrm{NH}_{2}$. When raw shoyu was applied to short columns of each agarose derivative, the adsorption of $\mathrm{AcP}$ occurred in a stepwise manner and the quantity of coagula in shoyu after heating decreased with the removal of AcP (Fig. 1). With increasing spacer length, the adsorption of AcP occurred in more numerous steps. The AcP was adsorbed in 2 steps when the spacer was $C_{2}, 3$ steps for $\mathrm{C}_{6}$ and 4 steps for $\mathrm{C}_{10}$, and the decrease in the quantity of coagula was similar to that of AcP. These results seem to suggest that AcP in the raw shoyu existed in four forms with different $K i$ toward pepstatin.

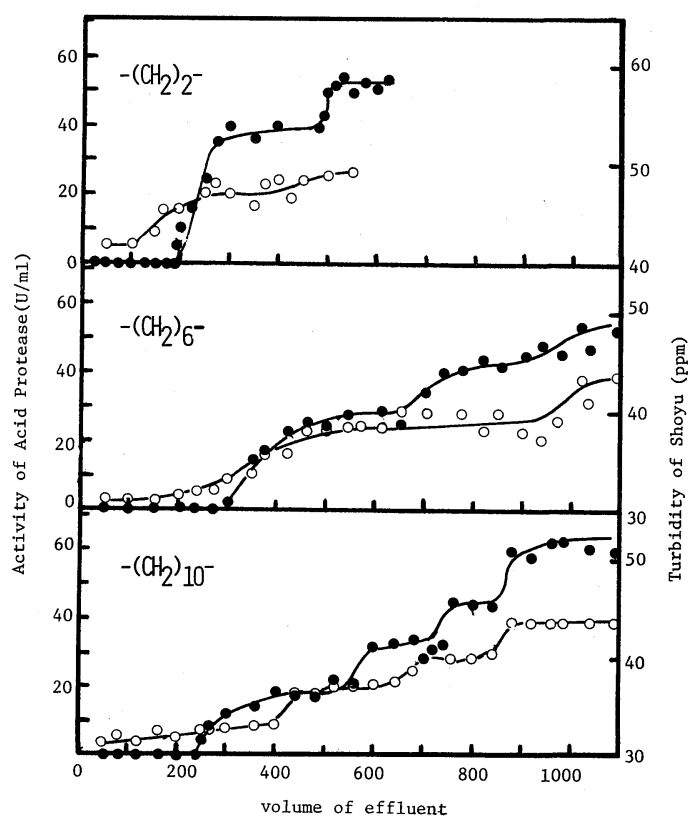

FIG. 1. Adsorption of AcP from Raw, Shoyu on Sepharose- $C_{n}$-Pepstatin.

A column $(0.6 \times 3.5 \mathrm{~cm})$ was first equilibrated with $0.05 \mathrm{M}$ acetate buffer (pH 4.5). Raw Shoyu $(1200 \mathrm{ml})$ was applied to the column at a flow rate of $7.2 \mathrm{ml} / \mathrm{hr}$. AcP activity (O) and coagula of shoyu after heating $(O)$ were measured. 


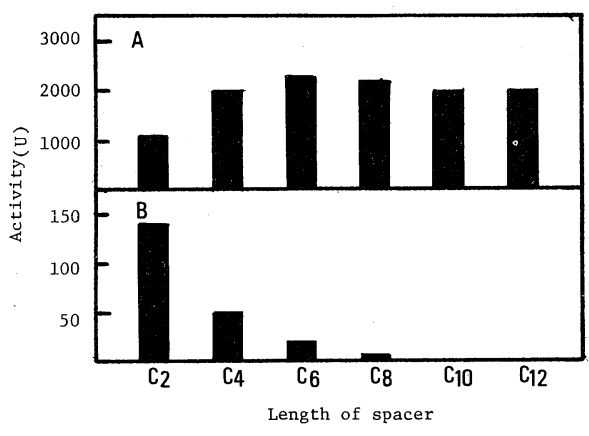

FIG. 2. Effects of the Length of the Spacer in Sepharose$\mathrm{C}_{n}$-Pepstatin on Adsorption and Elution of AcP. $500 \mathrm{mg}$ of each Sepharose- $\mathrm{C}_{n}$-pepstatin $(n=2,4,6,8,10$ and 12) was stirred for adsorption of AcP in affinity gel with $300 \mathrm{ml}$ of $s h o y u$ at $4^{\circ} \mathrm{C}$ for $24 \mathrm{hr}$. The shoyu was filtered and the remaining AcP activity in the filtrate was measured. Then absorbed AcP activity per $100 \mathrm{mg}$ of each affinity gel was calculated (A). $100 \mathrm{mg}$ of each affinity gel with adsorbed AcP was washed with $200 \mathrm{ml}$ of $0.05 \mathrm{M}$ acetate buffer ( $\mathrm{pH} 4.5$ ), and then AcP was eluted with $10 \mathrm{ml}$ of $0.05 \mathrm{M}$ acetate buffer $(\mathrm{pH} 3)$ containing $2 \mathrm{M}$ urea by slow stirring at $4^{\circ} \mathrm{C}$ for $2 \mathrm{hr}$. Each eluted AcP activity per $100 \mathrm{mg}$ of affinity gel was measured (B).

Figure 2 shows the effect of spacer length on the adsorption and elution of the AcP. When the spacer was $\mathrm{C}_{6}$, the quantity of adsorbed AcP was highest (Fig. 2A). Many investigators have used $\mathrm{C}_{6}$ as a spacer for purification of AcPs such as rennin, ${ }^{3,4)}$ renin, ${ }^{5)}$ etc., because of its high ability to adsorb those enzymes. Attempts to elute the AcP with glucose, glycerin or KSCN were unsuccessful, showing that AcP was tightly adsorbed to the affinity gel. Only urea made elution of the AcP possible. The quantity of eluted AcP increased as the carbon atoms of the spacer decreased (Fig. 2B). This result indicates that steric hindrance due to the shortening of the length of the spacer weakened the binding force of the AcP to pepstatin.

Conditions for elution of AcP from affinity gel

The influences of $\mathrm{pH}$ and urea concentration on elution of AcP were examined. The elution of protein was highest at $\mathrm{pH} 2$ and 7 in the $\mathrm{pH}$ range of $2 \sim 7$, but AcP activity was hardly observed. This shows that AcP is denatured at these unstable $\mathrm{pH}$ values (Fig. 3). On the other

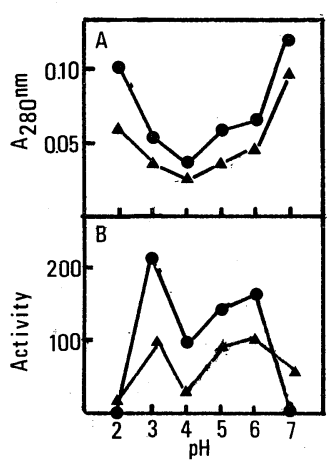

FIG. 3. Effect of $\mathrm{pH}$ on Elution of AcP from Sepharose$\mathrm{C}_{2}$-Pepstatin.

The elution conditions were the same as those given in Fig. 2 except for the $\mathrm{pH}$ and urea concentration; $\mathrm{pHs}$ were as indicated in the figure, and $1 \mathrm{~m}(\boldsymbol{\Delta})$ and $2 \mathrm{M}(\boldsymbol{O})$ urea were used. The absorbance at $280 \mathrm{~nm}$ (A) and the total activity of eluted AcP (B) were measured.

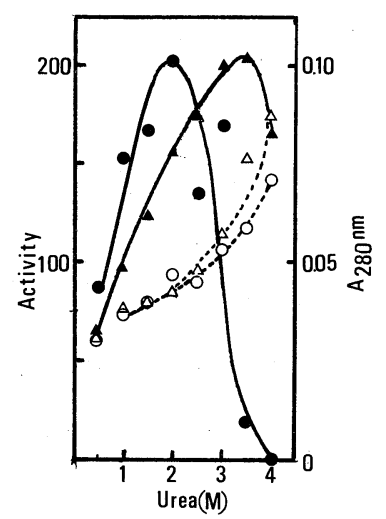

FIG. 4. Effect of Urea Concentration on Elution of AcP from Sepharose- $\mathrm{C}_{2}$-Pepstatin.

The conditions were the same as those given in Fig. 3. Total activity of eluted AcP (-) and absorbance at $280 \mathrm{~nm}$ $(--)$ were measured. [Eluted at $\mathrm{pH} 3(\boldsymbol{O}, \bigcirc)$ and $\mathrm{pH} 6(\boldsymbol{\Delta}$, $\triangle)]$

hand, recovery of AcP activity was highest at pH 3 and 6 (Fig. 3B). The conditions of pH 3 and $2 \mathrm{~m}$ urea, and $\mathrm{pH} 6$ and $3.5 \mathrm{~m}$ urea were the most useful for the recovery of the AcP (Fig. 4). The specific activity of AcP eluted at $\mathrm{pH} 3$ and $2 \mathrm{M}$ urea was higher than that at $\mathrm{pH} 6$ and $3.5 \mathrm{~m}$ urea. Therefore, the conditions of $0.05 \mathrm{M}$ acetate buffer $(\mathrm{pH} 3)$ containing $2 \mathrm{M}$ urea were adopted for the elution of the AcP from the affinity gel. In order to investigate whether the elution conditions make AcP inactive, the ef- 


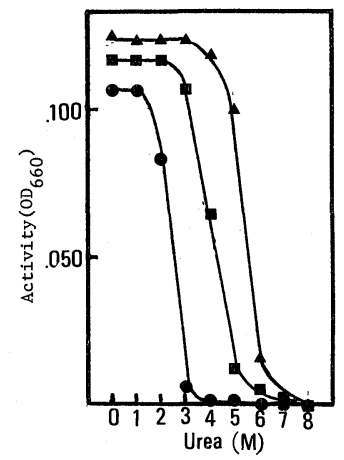

FIG. 5. Effects of $\mathrm{pH}$ and Urea Concentration on Denaturation of AcP.

Affinity chromatographed AcP was mixed with McIlvaine buffer containing various concentrations of urea at $\mathrm{pH} 3$

( $)$, $\mathrm{pH} 4.5(\boldsymbol{\Delta})$ and $\mathrm{pH} 6(\boldsymbol{\nabla})$. The mixtures were allowed to stand overnight at $4{ }^{\circ} \mathrm{C}$ and then remaining AcP activity was determined.

fect of the conditions on inactivation of the AcP was studied over the concentration and $\mathrm{pH}$ ranges of $0 \sim 8 \mathrm{M}$ urea and $3 \sim 6$ (Fig. 5). As for $\mathrm{pH}$, the AcP was the most stable at $\mathrm{pH} 4.5$, then at PH 6 and finally at $\mathrm{pH}$ 3. The AcP was inactivated by $2 \mathrm{M}$ urea at $\mathrm{pH} 3$ and by $3.5 \mathrm{M}$ urea at $\mathrm{pH}$ 6. These conditions agreed with those for the effective elution of the AcP from the pepstatin gel.

\section{Enzymatic characterization of AcP}

The AcP eluted with $2 \mathrm{M}$ urea in $0.05 \mathrm{M}$ acetate buffer ( $\mathrm{pH} 3$ ) from pepstatin-Sepharose $6 \mathrm{~B}$ showed one major and one minor band on disc gel electrophoresis (Fig. 6) and gel filtration with TSK-G3000SW (Fig. 7). Two peaks of AcP activity agreed with those of protein on gel filtration with TSK-G3000SW, respectively. Thus, both peaks in polyacrylamide gel were confirmed to be AcP. On the other hand, AcP activity in the raw shoyu showed four peaks on gel filtration with TSKG3000SW, that is, AcPs in the raw shoyu exist in four forms with different molecular sizes (Fig. 7). Affinity chromatographed AcP mainly consisted of two forms (main and minor peaks). The molecular weights of the two forms of purified AcP were calculated to be $6.7 \times 10^{4}$ and $4.5 \times 10^{4}$, respectively, by gel

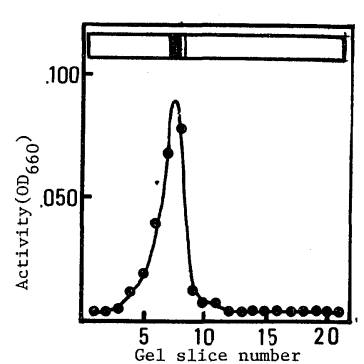

FIG. 6. Disc Gel Electrophoresis of Affinity Chromatographed AcP at $\mathrm{pH} 8.3$.

Portions of the eluted AcP from the affinity gel were submitted to electrophoresis at $\mathrm{pH} 8.3$ and each slice of the disc gel was extracted with $1 \mathrm{ml}$ of $0.05 \mathrm{M}$ acetate buffer ( $\mathrm{pH} 4.5$ ) after electrophoresis. Activity of extracted AcP was measured.

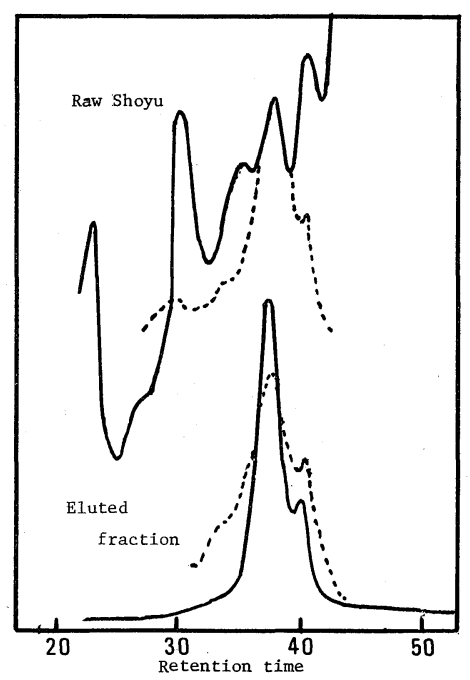

FIG. 7. Change in Chromatographic Pattern on a TSKG3000SW Column of Raw Shoyu and Eluted AcP from the Affinity Gel.

Ten drops of effluent from the TSK-G-3000SW column were collected, and AcP activity (---) and protein (-) were measured. Conditions: column, $2 \times$ TSK-G3000SW $(7.5 \times$ $60 \mathrm{~cm}$ ); samples, $5 \mu$ of raw shoyu or eluted AcP solution; solvent, $0.1 \mathrm{M} \mathrm{Na}_{2} \mathrm{SO}_{4}$ in $0.01 \mathrm{M}$ phosphate buffer ( $\mathrm{pH}$ 6.5); flow rate, $1.0 \mathrm{ml} / \mathrm{min}$; temperature, ambient; detector, absorbance at $220 \mathrm{~nm}$.

filtration with TSK-G3000SW. Figure 8 shows the effect of $\mathrm{pH}$ on the activation of trypsinogen and the proteolysis of hemoglobin by the AcP from the main peak. The optimum $\mathrm{pH}$ of the former was 3.5 and that of the latter 2.75. This agreed fairly well with that for AcP 
from $A$. sojae reported by Hayashi et al. ${ }^{18)}$ Thus, it was concluded that the purified AcP from raw shoyu originated from A. sojae. Generally, the separation of AcP and carboxypeptidase from $A$. sojae $e^{19)}$ or $A$. oryzae $e^{20)}$ has been very difficult, since both enzymes closely resemble each other in chemical and physical properties. The purified AcP prepared here did not contain any carboxypeptidase activity. Therefore, this procedure will be effective for the purification of $\mathrm{AcP}$ from Aspergillus. From the double reciprocal plots of $v$ versus $i$ where $v$ and $i$ are the initial rate and inhibitor concentration, respectively, the $K i$ value was estimated to be $1.0 \times 10^{-8} \mathrm{M}$. Many AcPs which were competitively inhibited by pepstatin have been purified by pepstatin affinity chromatography. But most of them have been easily eluted by changing to pHs under which they are unstable. ${ }^{3 \sim 5)}$ Table I

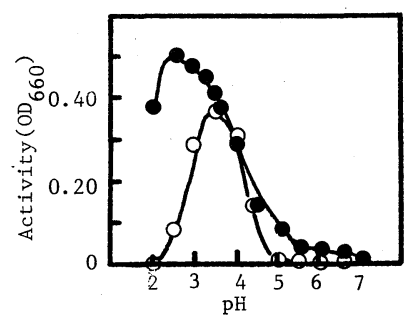

FIG. 8. Effect of $\mathrm{pH}$ on Activation of Trypsinogen and Hydrolysis of Hemoglobin by AcP.

The enzyme activities were measured as described in Materials AND Methods. McIlvaine buffer ( $\mathrm{pH} 3 \sim 7$ ) and acetate buffer ( $\mathrm{pH} 2.5$ and 2.0) were used. $\bigcirc$, activation of trypsinogen; $\mathbf{O}$, hydrolysis of hemoglobin. shows five examples of affinity chromatography in which it was difficult to elute the enzymes from pepstatin affinity gel, since the enzymes were tightly adsorbed to the pepstatin. Renin from human ${ }^{21)}$ and hog kidney ${ }^{22)}$ were eluted with denaturants such as urea, and their $K i$ values were more than $3.5 \times 10^{-7} \mathrm{M}$. Milk clotting enzymes could not be eluted because of their strong adsorption, but on use of $\mathrm{N}$-acetyl pepstatin instead of pepstatin, they could be eluted from the affinity gel. ${ }^{6}$ ) Thus the $K i$ limit value which allows elution of AcP on pepstatin affinity chromatography would be more than $1.0 \times 10^{-7} \mathrm{M}$. The $K i$ value for AcP presented here was the lowest of all those presented in Table I (1/10 of the limit value). Therefore, elution of the AcP was very difficult, because of the strong adsorption force. We found that the adsorption conditions were influenced by the length of the spacer between the ligand and the support, i.e. with a decrease in length of the spacer, the strength of adsorption decreased. Therefore, we did not use $\mathrm{C}_{6}$ as a spacer which was favoured by other investigators but employed $\mathrm{C}_{2}$ for the purification of the AcP from raw Shoyu by pepstatin affinity chromatography. Furthermore, by use of denaturants such as urea and unstable $\mathrm{pH}$ conditions, the AcP could be eluted from pepstatin affinity gel. Though it has been generally thought that the proper spacer length is needed for removing the steric hindrance between the ligand and adsorbed protein, steric hindrance caused

Table I. Comparison of Different Processes for Purification of AcP Having Low $K i$ by Pepstatin Affinity Chromatography

\begin{tabular}{|c|c|c|c|c|c|}
\hline & Enzyme & Substrate & $K i(\mathbf{M})$ & Eluent & $\begin{array}{l}\text { Length of } \\
\text { spacer }\end{array}$ \\
\hline A) & Renin (human) ${ }^{21)}$ & Angiotensinogen & $4.0 \times 10^{-6}$ & $4 \mathrm{~m}$ urea & $\mathrm{C}_{6}$ \\
\hline B) & $\operatorname{Renin}(h \circ g)^{22)}$ & Angiotensinogen & $3.5 \times 10^{-7}$ & $6 \mathrm{M}$ urea & $\mathrm{C}_{6}$ \\
\hline C) & $\begin{array}{l}\text { Milk clotting }{ }^{6)} \\
\text { enzyme (Mucor miehei) }\end{array}$ & Casein & $1.0 \times 10^{-7}$ & Not eluted & $\mathrm{C}_{6}$ \\
\hline D) & $\begin{array}{l}\text { Milk clotting } \\
\text { enzyme (Mucor miehei) }\end{array}$ & Casein & $\begin{array}{c}(N \text {-Acetyl-pepstatin }) \\
9.0 \times 10^{-7}\end{array}$ & $\mathrm{pH} 8.5$ & $\mathrm{C}_{6}$ \\
\hline \multicolumn{2}{|c|}{$\begin{array}{l}\text { Acid protease } \\
\text { from raw shoyu }\end{array}$} & Casein & $1.0 \times 10^{-8}$ & $\begin{array}{c}2 \mathrm{~m} \text { urea } \\
\mathrm{pH} 3.0\end{array}$ & $\mathrm{C}_{2}$ \\
\hline
\end{tabular}


by shortening the spacer was found to be useful for elution of strongly adsorbed protein. With the affinity chromatography system described here, the AcP and coagula could be recovered from the raw shoyu in one step. This was the first experiment in which useful enzymes were recovered from brewed products.

Acknowledgment. The authors are grateful to Professor E. Ichishima, Tokyo Nôkô University, for his kind suggestion, and Dr. T. Mizunuma, Kikkoman Corporation, for his encouragement.

\section{REFERENCES}

1) D. Fukushima, J. Am. Oil. Chem. Soc., 56, 357 (1979).

2) H. Hashimoto and T. Yokotsuka, J. Ferment. Technol., 52, 747 (1978).

3) H. Kobayashi and K. Murakami, Agric. Biol. Chem., 42, 2227 (1978).

4) H. Kobayashi and K. Murakami, Abstracts of Papers, Annual Meeting of the Agricultural Chemical Society of Japan, Nagoya, April, 1978, p. 319.

5) K. Murakami and T. Inagami, Biochem. Biophys. Res. Commun., 62, 757 (1975).

6) H. Kobayashi, I. Kusakabe and K. Murakami, Anal. Biochem., 122, 308 (1981).

7) H. Motai, K. Hayashi, T. Ishiyama and G.
Sonehara, Nippon Nôgeikagaku Kaishi, 57, 27 (1983).

8) M. L. Anson, J. Gen. Physiol., 22, 79 (1938).

9) C. Gabeloteau and P. Deuelle, Biochim. Biophys. Acta, 42, 230 (1960).

10) J. P. Abita, M. Delaage and M. Lazounski, Eur. J. Biochem., 8, 314 (1969).

11) E. Ichishima, Biochim. Biophys. Acta, 258, 274 (1972).

12) M. Dixon, Biochem. J., 55, 170 (1953).

13) D. E. Williams and R. A. Reisfeld, Ann. N. Y. Acad. Sci., 121, 373 (1964).

14) O. H. Lowry, N. J. Rosebrough, A. L. Farr and R. J. Randall, J. Biol. Chem., 193, 265 (1951).

15) J. Turková, "Journal of Chromatography Library," Vol. 12, ed. by J. Turková, Elsevier Scientific Publishing Company, Amsterdam, 1978, p. 151.

16) Y. Tsujita and A. Endo, J. Bacteriol., 130, 48 (1977).

17) T. Nakadai, Nippon Shoyu Kenkyu-sho Zasshi, 3, 99 (1977).

18) K. Hayashi, Abstracts of Papers, Annual Meeting of the Agricultural Chemical Society of Japan, Tokyo, April, 1974, p. 42.

19) T. Kimura, Y. Mayumi, M. Takeuchi, K. Hayashi and E. Ichishima, Current Microbiology, 3, 153 (1979).

20) T. Nakadai and S. Nasuno, Agric. Biol. Chem., 41, 409 (1977).

21) C. Devaux, P. Corvol and J. Menard, Biochim. Biophys. Acta, 359, 421 (1974).

22) P. Corvol, C. Devaux and J. Menard, FEBS Lett., 34, 189 (1973). 